\title{
Validation of Calculated Thermal Parameters with Experimental Results in SOFCs
}

\author{
Saeed Ghali*, Azza Ahmed, Taha Mattar \\ Steel Technology Department, Central Metallurgical Research \& Development Institute (CMRDI), \\ Cairo, Egypt \\ Email: *a3708052@yahoo.com
}

How to cite this paper: Ghali, S., Ahmed, A. and Mattar, T. (2018) Validation of Calculated Thermal Parameters with Experimental Results in SOFCs. Journal of Minerals and Materials Characterization and Engineering, 6, 193-202.

https://doi.org/10.4236/jmmce.2018.62014

Received: November 11, 2017

Accepted: March 17, 2018

Published: March 20, 2018

Copyright $\odot 2018$ by authors and Scientific Research Publishing Inc. This work is licensed under the Creative Commons Attribution International License (CC BY 4.0).

http://creativecommons.org/licenses/by/4.0/

\begin{abstract}
Eleven steel grades were designed to be used as metallic interconnects for Solid Oxide Fuel Cells (SOFC). Low carbon, high chromium steel with different additives of niobium, vanadium, aluminum, molybdenum, silicon, manganese and titanium were produced. Phase transformation temperatures; eutectoid temperature (Ac1) and temperature at which transformation of ferrite to austenite is completed during heating (Ac3) were measured by L75-76 dilatometer. The influence of the alloying elements on transformation temperatures was analyzed using MATLab. Considering the interaction between different alloying elements two equations for predicting Ac1 \& Ac3 were obtained. The obtained Ac1 \& Ac3 by these equations showed more compatibility than that obtained by traditional ones. In addition, the coefficients of thermal expansion of these steel grades were detected. The influences of chemical composition and temperature on the thermal expansion coefficient were analyzed; the obtained equations were verified to certain extent by using several kinds of steels. The predicted values were in good accordance with the experimental results which proof the validation of calculation model.
\end{abstract}

\section{Keywords}

Transformation Temperature, Thermal Expansion Coefficient, SOFCs Steel, Matlab

\section{Introduction}

Recent research results have enabled to decrease the operating temperature of the Solid Oxide Fuel Cells (SOFCs) from $1000^{\circ} \mathrm{C}$ to $800^{\circ} \mathrm{C}$ [1]. This progress has been made by reducing the thickness of the electrolyte [2] and improving the cathode electrolyte interface reaction (i.e. Triple Phases Boundaries (TPB) to In- 
ternal Diffusion (ID) mechanism) [3]. The lower operating temperature authorises metallic alloys as possible candidates for interconnects [4]. Solid oxide fuel cells (SOFC) are environmental friendly energy conversion device with high efficiency and prolonged-ranging fuel utilization [5]. The thermal expansion coefficient (TEC) of interconnects should be around $10-13 \times 10^{-6} \mathrm{~K}^{-1}$ [6] [7]. It was reported that the rare earth elements and their oxides can be used to decrease the oxidation rate [8] [9].

Metallic materials have higher electrical and thermal conductivities, are easier to fabricate, and, in general, have lower cost compared to the ceramic interconnects [4] [10]. Chromium is the most important element because of the formation of chromia as protective and semiconducting layer. The presence of other elements could improve the characteristics of this layer, limiting the growth rate and the acceptable area-specific resistance (ASR), reducing the poisoning of the electrodes due to the oxidation gaseous species $\left(\mathrm{CrO}_{3}\right.$ or $\left.\mathrm{CrO}_{2}(\mathrm{OH})_{2}\right)$ at temperatures close to $1000^{\circ} \mathrm{C}$ and higher [11] [12], but also observed at lower temperatures due to the severe operation conditions, such as the presence of water vapor [11] [12] [13] [14] [15]. The formation of a protective, single-phase chromium layer requires chromium content of approximately 17\% - 20\% [10] [16]-[21], depending on the temperature, surface treatment and minor alloying additions. $\mathrm{Mn}$ and $\mathrm{Ti}$ are used in a few tenths of the percent to improve the oxidation resistance. Mn tends to form a Cr-Mn spinel on the external surface layer to decrease the formation of volatile $\mathrm{Cr}$ species [10] [11] [17] [22] [23] [24].

Although the influences of chemical composition on transformation temperatures have been studied since the 1960s and several equations suitable for different situations were deduced by analyzing the corresponding data of hundreds types of steels [25] [26] [27], these classic equations were not high precise and not effective, as these analyses were too general and many types of steels were involved. Furthermore, as these analyses were mainly multiple linear regressions, the interactions of the alloying elements were seldom considered. In view of these facts, the phase transformation temperatures of SOFCs steel were studied systematically in this research. Two equations were obtained to predict Acl and Ac3 considering the effect of chemical compositions. The predicted Ac1 and Ac3 by designed equations are compared with the traditional ones.

In the case of SOFCs steel, small thermal expansion is required because higher coefficients always mean higher stresses during the periodic process of heating and cooling. Generally, coefficients of thermal expansion of steel will increase along with the increase in the total content of the alloying elements. The influences of the interactions of the elements on the coefficient are more complicated. Therefore, the thermal expansion coefficients of the samples at annealed state are also measured. Model has been established to predict the thermal expansion coefficient as a function of chemical composition and temperature. The novelty of this work; the effect of the interaction combination among different alloying elements and/or temperature on Ac1, Ac3 and thermal expansion coefficient was 
taken into consideration.

\section{Experimental}

Eleven developed ferritic stainless steel (SOFCs) with different refractory alloying elements additives were melted in induction furnace of capacity $10 \mathrm{~kg}$ and cast in sand mold. Complete chemical analysis has been carried out for all cast steels. The cast steels were normalized at $1000^{\circ} \mathrm{C}$ for 4 hours, followed by open radial forging. Ingots with square diameter $65 \mathrm{~mm}$ were hot forged to about 35 $\mathrm{mm}$ square. The steel were reheated up to $1200^{\circ} \mathrm{C}$ and hold for 2 hours before start forging. Starting forging temperature was $1150^{\circ} \mathrm{C}$ while forging process was ended at temperatures $950^{\circ} \mathrm{C}$.

Thermal expansion measurements were carried out with L75-76 dilatometer. The specimens were prepared by machining from each steels to form a rectangular shape with the dimensions $(3 \times 3 \times 30 \mathrm{~mm})$ and polished through 600 grit prior to testing. Ac1 \& Ac3 are estimated from the expansion curve against the temperature. The change in coefficient of thermal expansion was recorded during heating of the sample from room temperature to $1000 \mathrm{oC}$ and cooling from 1000 to $500 \mathrm{oC}$. Two square matrices-of 10 th degree-were designed as function of alloying elements and measured Ac1 or Ac3. Also, High order square matrix was designed between the alloying elements, thermal expansion coefficient at each temperature. MATLab was used to solve these higher order matrices to get Ac1, Ac3 and thermal expansion coefficient as function in alloying elements (for Ac1 and Ac3) and temperature (Thermal expansion coefficient).

\section{Result and Discussion}

The chemical composition of developed SOFCs ferritic steel grades are listed in Table 1. With L75-76 dilatometer, the transformation temperatures Ac1 \& Ac3 of the investigated steels were measured, and the results are shown in Table 2.

The data listed in Table 1 and Table 2 was analyzed using MATLab. The relationships between the chemical composition and phase transformation temperatures, Ac1 and Ac3, were studied, where two corresponding equations were deduced as follows:

$$
\begin{aligned}
\text { Ac1 }= & 45791.55 *[\mathrm{C} \%]-150.551 *[\mathrm{Si} \%]+1385.216 *[\mathrm{Mn} \%]-27.208 *[\mathrm{Cr} \%] \\
& +495.9697 *[\mathrm{Mo} \%]-700.922 *[\mathrm{Nb} \%]+39115.62 *[\mathrm{~V} \%] \\
& -982.165 *[\mathrm{Mn} \%]^{2}-1606.56 *[\mathrm{Cr} \%] *[\mathrm{C} \%] \\
& -7448.37 *[(\mathrm{Nb}+\mathrm{V}+\mathrm{Mo}) \%] *[\mathrm{C} \%] \\
\text { Ac3 }= & 43732.4 *[\mathrm{C} \%]-161.931 *[\mathrm{Si} \%]+1294.837 *[\mathrm{Mn} \%]-25.4274 *[\mathrm{Cr} \%] \\
& +484.8949 *[\mathrm{Mo} \%]-606.577 *[\mathrm{Nb} \%]+38400.17 *[\mathrm{~V} \%] \\
& -923.807 *[\mathrm{Mn} \%]^{2}-1509.54 *[\mathrm{Cr} \%] *[\mathrm{C} \%] \\
& -7417.06 *[(\mathrm{Nb}+\mathrm{V}+\mathrm{Mo}) \%] *[\mathrm{C} \%]
\end{aligned}
$$

From Equations (1) \& (2), it can be seen that, the carbon has a positive effect 
Table 1. Chemical composition of $\mathrm{SOFC}_{\mathrm{S}}$ steel grades, wt $\%$.

\begin{tabular}{cccccccccc}
\hline Heat No. & $\mathrm{C}$ & $\mathrm{Si}$ & $\mathrm{Mn}$ & $\mathrm{Cr}$ & $\mathrm{Mo}$ & $\mathrm{Al}$ & $\mathrm{Nb}$ & $\mathrm{Ti}$ & $\mathrm{V}$ \\
\hline $\mathbf{1}$ & 0.060 & 2.00 & 0.62 & 33.01 & 0.052 & 0.0001 & 0.0040 & 0.0037 & 0.043 \\
$\mathbf{2}$ & 0.079 & 0.35 & 1.55 & 25.16 & 0.060 & 0.0005 & 0.0029 & 0.0031 & 0.029 \\
$\mathbf{3}$ & 0.177 & 0.37 & 0.08 & 23.43 & 1.150 & 0.0167 & 0.0051 & 0.0032 & 0.018 \\
$\mathbf{4}$ & 0.065 & 1.13 & 0.08 & 22.11 & 0.049 & 0.0072 & 0.0057 & 0.0029 & 0.021 \\
$\mathbf{5}$ & 0.067 & 0.29 & 0.14 & 25.94 & 0.050 & 0.0256 & 0.0020 & 0.0781 & 0.024 \\
$\mathbf{6}$ & 0.101 & 2.20 & 0.85 & 23.30 & 0.906 & 0.0212 & 0.6190 & 0.0602 & 0.036 \\
$\mathbf{7}$ & 0.055 & 1.05 & 0.13 & 25.71 & 0.909 & 0.0105 & 0.0303 & 0.0083 & 0.024 \\
$\mathbf{8}$ & 0.078 & 1.25 & 0.83 & 28.81 & 0.043 & 0.0105 & 0.0076 & 0.0923 & 0.028 \\
$\mathbf{9}$ & 0.063 & 2.64 & 0.27 & 30.46 & 0.052 & 0.6550 & 0.0004 & 0.0107 & 0.042 \\
$\mathbf{1 0}$ & 0.051 & 0.43 & 0.17 & 27.13 & 0.054 & 1.5700 & 0.0044 & 0.0067 & 0.026 \\
$\mathbf{1 1}$ & 0.076 & 0.38 & 1.41 & 25.10 & 1.160 & 0.0217 & 0.0026 & 0.0032 & 0.025 \\
\hline
\end{tabular}

Table 2. Measured transformation temperatures of the investigated steels, ${ }^{\circ} \mathrm{C}$.

\begin{tabular}{ccc}
\hline Heat No. & Ac1 $\left({ }^{\circ} \mathrm{C}\right)$ & Ac3 $\left({ }^{\circ} \mathrm{C}\right)$ \\
\hline 1 & 520 & 720 \\
2 & 560 & 650 \\
3 & 500 & 720 \\
4 & 680 & 840 \\
5 & 530 & 640 \\
6 & 500 & 610 \\
7 & 480 & 780 \\
8 & 480 & 630 \\
9 & 460 & 610 \\
10 & 480 & 720 \\
11 & 480 & 700 \\
\hline
\end{tabular}

on increasing both $\mathrm{Ac1} \& \mathrm{Ac} 3$. But in presence of $\mathrm{Cr}, \mathrm{Nb}, \mathrm{V}$ and $\mathrm{Mo}$; carbon will cause decreasing in both $\mathrm{Ac} 1 \& \mathrm{Ac} 3$. On the other hand, $\mathrm{Si}, \mathrm{Cr}$ and $\mathrm{Nb}$ have a tendency to lower Ac1 \& Ac3 but Mo and V have a significant effect in increasing both Ac1 \& Ac3. Meanwhile Mn has a special effect as its effect is the sum of two opposite effect; the first is positive one which related to the manganese content of the metal to the power one while the second effect related to the manganese content of the metal to the power two. This means that Mn might increase or decrease Ac1 \& Ac3 depending on its content in steel. Generally, within the range of this study, $\mathrm{V}$ and $\mathrm{Cr}$ are the main alloying elements that affected phase transformation temperatures, whereas, $\mathrm{Mn}, \mathrm{C}, \mathrm{Mo}$, and Si were the less important ones. 
The coefficients of thermal expansion $(\alpha)$ of annealed SOFCs steel grades at different temperatures are listed in Table 3. On the basis of the data listed in Table 1 and Table 3, the influences of chemical composition and temperature on the thermal expansion coefficient of different steel grades were studied, and an equation was deduced to predict the thermal expansion coefficient as a function of alloying elements and temperature as given in Equation (3)

$$
\begin{aligned}
& \text { Thermal Expansion }(\alpha)\left(* 10^{-6}\right) \\
& \begin{aligned}
= & 240 *[\mathrm{C} \%]+1.99 *[\mathrm{Si} \%]+0.489 *[\mathrm{Mn} \%]+0.249 *[\mathrm{Cr} \%]+5.41 *[\mathrm{Mo} \%] \\
& -3.63 *[\mathrm{Al} \%]-7.13 *[\mathrm{Cr} \%] *[\mathrm{C} \%]-62.9 *[\mathrm{Mo} \%] *[\mathrm{C} \%] \\
& -66.3 *[(\mathrm{Nb}+\mathrm{Ti}+\mathrm{V}) \%] *[\mathrm{C} \%]+0.004416 * \mathrm{~T}-3.532468
\end{aligned}
\end{aligned}
$$

From Equation (3), it can be noticed that: $\mathrm{Mn}, \mathrm{Si}, \mathrm{Mo}, \mathrm{Cr}$ and $\mathrm{C}$ have a tendency to increase $\alpha$, but the increasing effect is restrained by the presence of $\mathrm{Al}$ and carbides of $\mathrm{Mn}, \mathrm{Nb}, \mathrm{Mo}, \mathrm{Nb}, \mathrm{Ti}, \mathrm{V}$. At the same time the temperature has small effect on increasing coefficient of thermal expansion.

In this section, the calculated thermal expansion by Equation (3) is compared by that obtained by applying the traditional Equations (4)-(5), which were given by Andrews [20] [21] and modern Equations (6)-(7) given by XIE Hao-jie [28]:

$$
\begin{aligned}
\text { Ac1 }= & 723-10.7 *[\mathrm{Mn} \%]-16.9 *[\mathrm{Ni} \%]+29 *[\mathrm{Si}] \\
& +16.9 *[\mathrm{Cr}]+290 *[\mathrm{As} \%]+6.38 *[\mathrm{~W} \%] \\
\text { Ac3 }= & 910-203 *[\mathrm{C} \%]^{1 / 2}-15.2 *[\mathrm{Ni} \%]+44.7 *[\mathrm{Si} \%] \\
& +104 *[\mathrm{~V} \%]+31.5 *[\mathrm{Mo} \%]+13.1 *[\mathrm{~W} \%] \\
\text { Ac1 }= & 36.57605 *[\mathrm{Mn} \%]-6.279322 *[\mathrm{C} \%] *[\mathrm{Cr} \%] \\
& -74.38445 *[\mathrm{C} \%] *[\mathrm{~V} \%]-51.62571 *[\mathrm{Mn} \%]^{2}+858.9063 \\
\text { Ac3 }= & 777.1057+52.85982 *[\mathrm{C} \%] *[\mathrm{Cr} \%]-10.23115 *[\mathrm{Cr} \%] *[\mathrm{Mo} \%] \\
& +72.39112 *[\mathrm{~V} \%] 2+26.68782 *[\mathrm{Mo} \%] *[\mathrm{~V} \%]
\end{aligned}
$$

Table 3. Experimental result of thermal expansion coefficients of the steels $\left(\mathrm{X} 10^{-6} /{ }^{\circ} \mathrm{C}\right)$.

\begin{tabular}{cccccccccc}
\hline Heat No. & $30^{\circ} \mathrm{C}$ & $100^{\circ} \mathrm{C}$ & $200^{\circ} \mathrm{C}$ & $300^{\circ} \mathrm{C}$ & $400^{\circ} \mathrm{C}$ & $500^{\circ} \mathrm{C}$ & $600^{\circ} \mathrm{C}$ & $700^{\circ} \mathrm{C}$ & $800^{\circ} \mathrm{C}$ \\
\hline $\mathbf{1}$ & 9.2 & 10.4 & 10.93 & 11.37 & 11.55 & 11.65 & 11.66 & 12.14 & 12.66 \\
$\mathbf{2}$ & 9.0 & 10.57 & 10.99 & 11.45 & 11.66 & 11.73 & 11.65 & 11.98 & 12.33 \\
$\mathbf{3}$ & 8.99 & 10.62 & 11.25 & 11.69 & 11.85 & 11.81 & 11.62 & 11.88 & 12.55 \\
$\mathbf{4}$ & 8.62 & 10.73 & 11.42 & 11.91 & 12.21 & 12.44 & 12.62 & 12.83 & 13.04 \\
$\mathbf{5}$ & 8.81 & 10.84 & 11.83 & 12.38 & 12.57 & 12.64 & 12.51 & 12.83 & 13.25 \\
$\mathbf{6}$ & 8.67 & 10.34 & 10.97 & 11.46 & 11.67 & 11.73 & 11.67 & 11.97 & 12.34 \\
$\mathbf{7}$ & 8.81 & 10.33 & 10.82 & 11.30 & 11.53 & 11.62 & 11.52 & 11.81 & 12.08 \\
$\mathbf{8}$ & 8.79 & 10.32 & 10.77 & 11.23 & 11.40 & 11.49 & 11.34 & 11.65 & 12.09 \\
$\mathbf{9}$ & 9.19 & 10.65 & 11.24 & 11.71 & 11.86 & 11.74 & 11.60 & 11.95 & 11.88 \\
10 & 8.70 & 10.39 & 11.07 & 11.57 & 11.76 & 11.77 & 11.62 & 11.92 & 12.56 \\
11 & 8.75 & 10.32 & 10.80 & 11.26 & 11.47 & 11.60 & 11.52 & 11.72 & 12.82 \\
\hline
\end{tabular}


It should be mentioned that Equation (4) and Equation (5) were obtained by considering the influence of every single alloying element on the corresponding phase transformation, temperature only, whereas, Equation (6) and Equation (7) were deduced with consideration of the interaction of the alloying elements.

On the basis of the chemical composition of different steel grades as listed in Table 1, the phase transformation temperatures (Ac1 \& Ac3) of the steels were calculated using Equations (1)-(2) and Equations (4)-(7). The calculated values of both Ac1 and Ac3 are listed in Table 4 and represented in Figures 1-2 respectively.

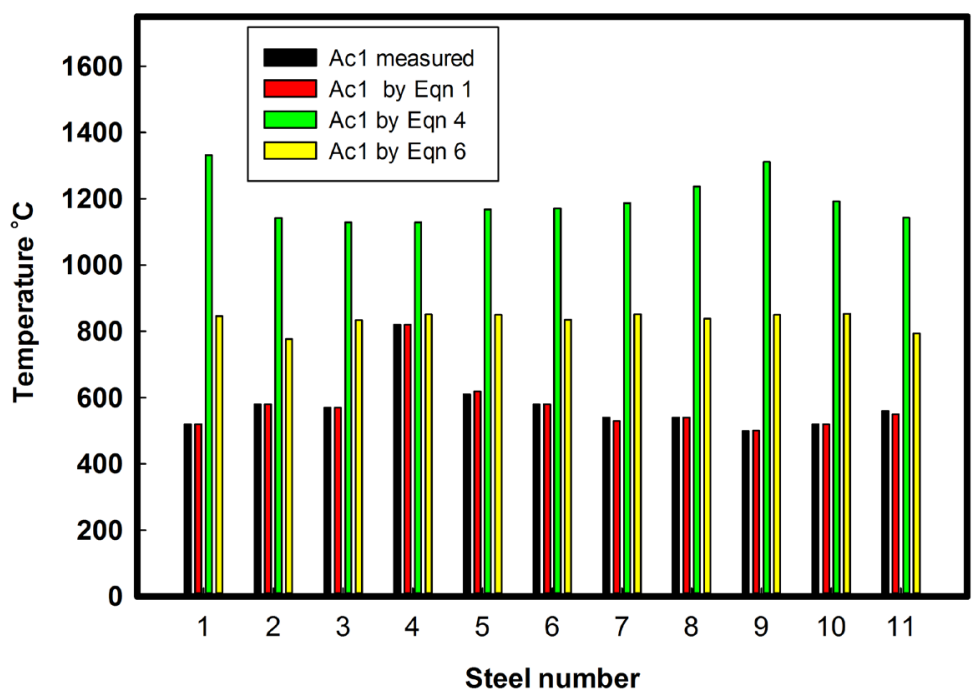

Figure 1. Variation between the measured Acl values with the estimated values of the authors (Equation (1)), Andrews [20] [21] (Equation (4)) and XIE Hao-jie [28] (Equation (6)).

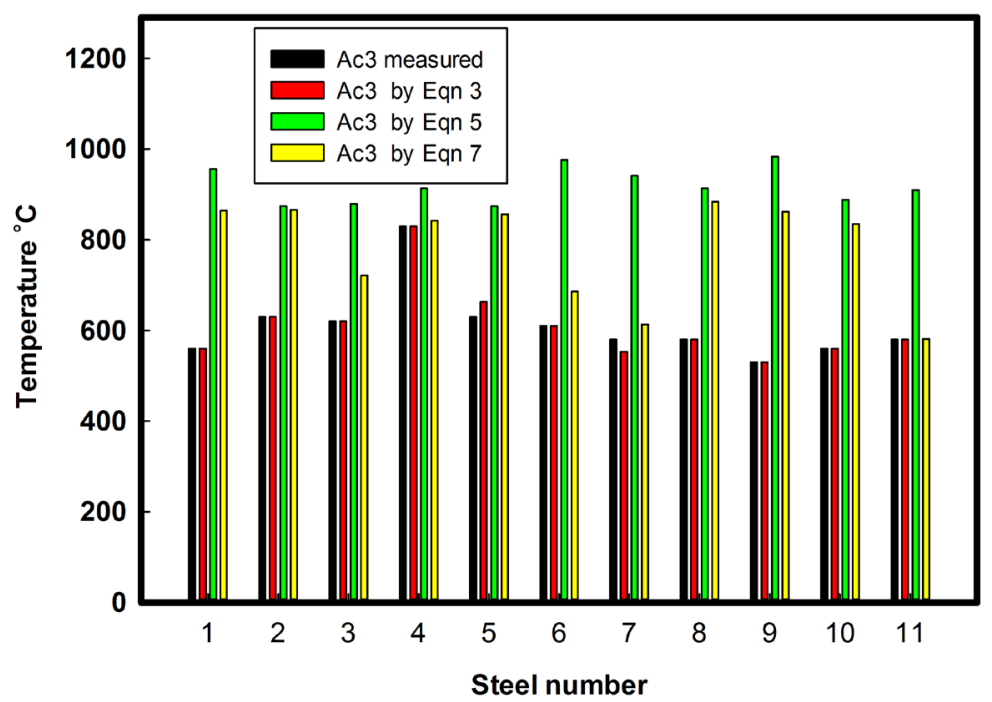

Figure 2. Variation between the measured Ac3 values with the estimated values of the authors (Equation (2)), Andrews [20] [21] (Equation (5)) and XIE Hao-jie [28] (Equation (7)). 
Table 4. Validity of calculated phase transformation temperatures with experimental results.

\begin{tabular}{ccccccccc}
\hline \multirow{2}{*}{ Heat No. } & \multicolumn{3}{c}{ Ac1 } & \multicolumn{5}{c}{ Ac3 } \\
\cline { 2 - 8 } & Measured & Equation (1) & Equation (4) & Equation (6) & Measured & Equation (2) & Equation (5) & Equation (7) \\
\hline $\mathbf{1}$ & 520 & 520.0 & 1332 & 846 & 560 & 560.0 & 956 & 864 \\
$\mathbf{2}$ & 580 & 580.0 & 1142 & 777 & 630 & 630.0 & 874 & 866 \\
$\mathbf{3}$ & 570 & 570.0 & 1129 & 834 & 620 & 620.0 & 879 & 721 \\
$\mathbf{4}$ & 820 & 820.0 & 1129 & 851 & 830 & 830.0 & 913 & 842 \\
$\mathbf{5}$ & 610 & 618.1 & 1168 & 850 & 630 & 662.7 & 874 & 856 \\
$\mathbf{6}$ & 580 & 580.0 & 1171 & 835 & 610 & 610.0 & 976 & 686 \\
$\mathbf{7}$ & 540 & 529.1 & 1187 & 852 & 580 & 553.3 & 941 & 613 \\
$\mathbf{8}$ & 540 & 540.0 & 1237 & 838 & 580 & 580.0 & 913 & 884 \\
$\mathbf{9}$ & 500 & 500.3 & 1311 & 850 & 530 & 530.2 & 983 & 862 \\
$\mathbf{1 0}$ & 520 & 520.0 & 1192 & 853 & 560 & 560.0 & 888 & 835 \\
$\mathbf{1 1}$ & 560 & 550.0 & 1143 & 794 & 580 & 580.0 & 910 & 581 \\
\hline
\end{tabular}

It can be noticed that as illustrated in Figures 1-2, the values obtained by Equations (6)-(7) are more close to the measured one than that obtained by Equations (4)-(5). This is because Equations (6)-(7) take into consideration the interaction between the elements. On the other hand, the values calculated by the current work, Equations (1)-(2), are more consistent with the experimental values than that obtained by Equations (4)-(7).

The measured thermal expansion coefficients of the investigated annealed SOFCs steel grades were compared with that estimated by Equation (3) which designed by current work and Equation (8) which designed by XIE Hao-jie [28]. The measured and estimated values of thermal expansion coefficients are given in Table 5.

$$
\begin{aligned}
& \text { Thermal Expansion Coefficient }(\alpha) \\
& \begin{aligned}
= & -0.530592 *[\mathrm{Si} \%] *[\mathrm{~V} \%]+0.696172 *[\mathrm{Mn} \%] *[\mathrm{Mo} \%] \\
& -0.173824 *[\mathrm{Cr} \%] *[\mathrm{Mo} \%]+0.001401 *[\mathrm{Cr} \%] * \mathrm{~T} \\
& +0.001966 *[\mathrm{~V} \%] * \mathrm{~T}-0.000005 \mathrm{~T}^{2}+11.8656
\end{aligned}
\end{aligned}
$$

It can be noticed that, for the steels tested in this experiment, the predicted values by current work equation, Equation (3), are more consistent with the experimental values than that obtained by Equation (8). This may be due to Equation (3) take into consideration the effect of the carbon and Aluminum.

\section{Conclusion}

It is difficult to build up equation to predict Ac1, Ac3 and thermal expansion coefficient for a wide range of chemical compositions of different steel grades. But it is possible to build up Equations to predict Ac1, Ac3 and coefficient of thermal expansion for limited chemical composition range for certain steel 
Table 5. Thermal expansion coefficients of the steels $\left(\mathrm{X} 10^{-6} /{ }^{\circ} \mathrm{C}\right)$, measured, expected by Equations (3) \& (8).

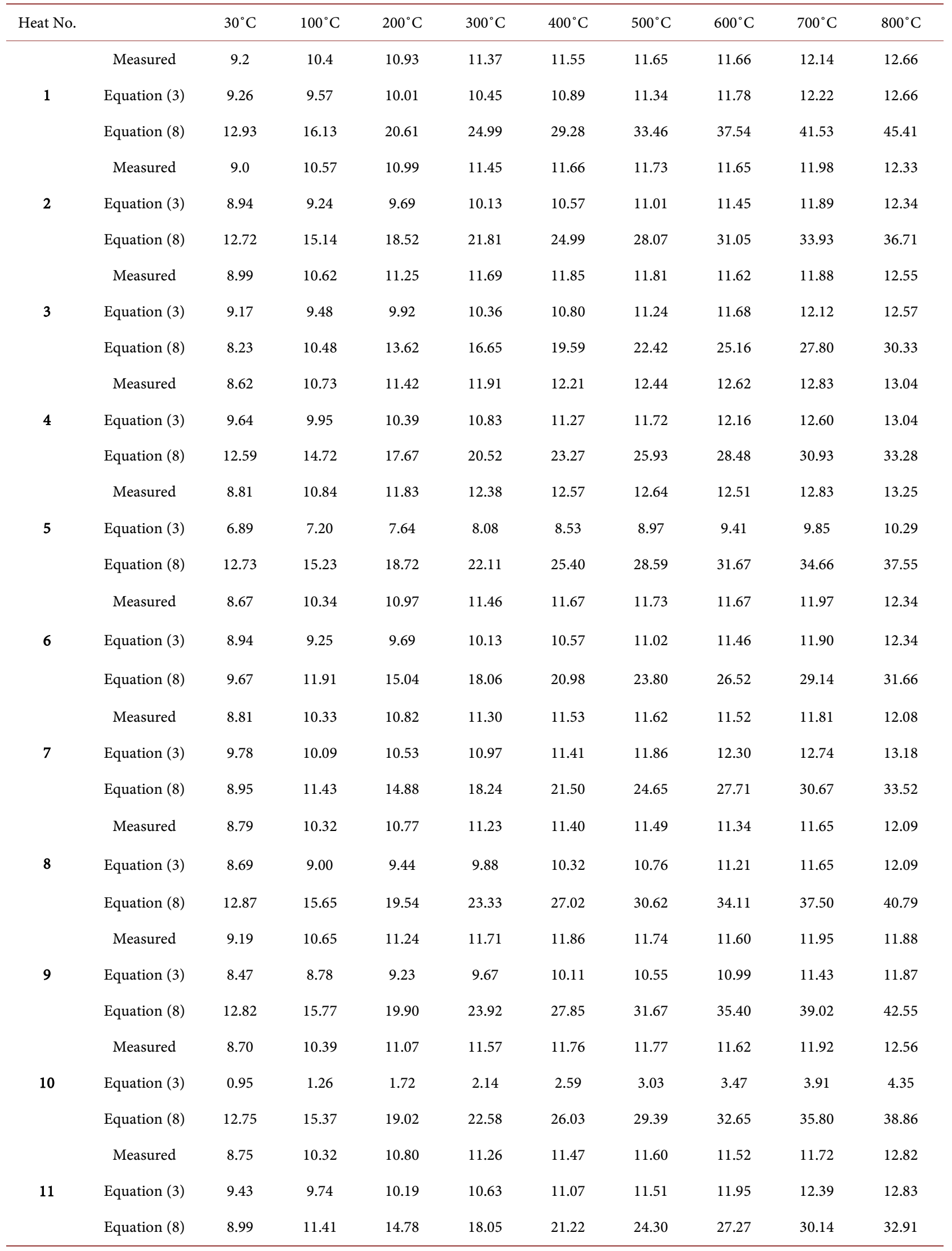


category. For SOFCs steel grades, within range of chemical compositions $(0.0506 \%$ - $0.101 \%$ C, $0.354 \%$ - 2.2\% Si, 0.0808\% - 1.55\% Mn, 25.1\% - 33.01\% Cr, 0.0427\% - $1.1 \%$ Mo, $0.0001 \%$ - 1.5\% Al, 0.0004\% - 0.0923\% Nb and 0.0177\% - 0.0433\% V) Ac1 and Ac3 Eqns. were deduced as a function in chemical composition. It could be concluded also that, coefficient of thermal expansion can be predicted as a function in chemical composition and temperature.

\section{References}

[1] Wachsman, E.D. and Lee, K.T. (2011) Lowering the Temperature of Solid Oxide Fuel Cells. Science, 334, 935-939. https://doi.org/10.1126/science.1204090

[2] Kosacki, I., Rouleau, C.M., Becher, P.F., Bentley, J. and Lowndes, D.H. (2005) Nanoscale Effects on the Ionic Conductivity in Highly Textured YSZ Thin Films. Solid State Ionics, 176, 1319-1326. https://doi.org/10.1016/j.ssi.2005.02.021

[3] Mauvy, F., Bassat, J.-M., Boehm, E., Manaud, J.-P., Dordor, P. and Grenier, J.-C. (2003) Oxygen Electrode Reaction on $\mathrm{Nd}_{2} \mathrm{NiO}_{4+\delta}$ Cathode Materials: Impedance Spectroscopy Study. Solid State Ionics, 158, 17-28. https://doi.org/10.1016/S0167-2738(02)00689-6

[4] Antoni, L. (2004) Materials for Solid Oxide Fuel Cells: The Challenge of Their Stability. Materials Science Forum, 461-464, 1073-1090. https://doi.org/10.4028/www.scientific.net/MSF.461-464.1073

[5] Kisa, A.E. and Demircan, O. (2017) Synthesis and Characterization of $\mathrm{La}_{0.595} \mathrm{~V}_{0.005}$ $\mathrm{Sr}_{0.4} \mathrm{CoO}_{3-\delta}$ as a Novel Cathode Material for Solid Oxide Fuel Cells (SOFC). Journal of Sol-Gel Science and Technology, 82, 352-362. https://doi.org/10.1007/s10971-017-4334-y

[6] Wu, J. and Liu, X. (2010) Recent Development of SOFC Metallic Interconnect. Journal of Materials Science and Technology, 26, 293-305. https://doi.org/10.1016/S1005-0302(10)60049-7

[7] Mercadelli, E., Gondolini, A., Pinasco, P. and Sanson, A. (2017) Stainless Steel Porous Substrates Produced by Tape Casting. Metals and Materials International, 23, 184-192. https://doi.org/10.1007/s12540-017-6336-2

[8] Lee, J.-W., Mehran, M.T., Song, R.-H., Lee, S.-B., Lee, J.-W., Lim, T.-H., Park, S.-J., Hong, J.-E. and Shim, J.-H. (2017) Effects of $\mathrm{La}_{2} \mathrm{O}_{3}$ Content and Particle Size on the Long-Term Stability and Thermal Cycling Property of $\mathrm{La}_{2} \mathrm{O}_{3}$-Dispersed SUS430 Alloys for SOFC Interconnect Materials. Metals and Materials International, 23, 1250-1256. https://doi.org/10.1007/s12540-017-7079-9

[9] Ramanathan, L.V., Pillis, M.F. and Fernandes, S.M.C. (2007) Role of Rare Earth Oxide Coatings on Oxidation Resistance of Chromia-Forming Alloys. Journal of Materials Science, 43, 530-535. https://doi.org/10.1007/s10853-007-1855-8

[10] Fergus, J.W. (2005) Metallic Interconnects for Solid Oxide Fuel Cells. Materials Science and Engineering A, 397, 271-283. https://doi.org/10.1016/j.msea.2005.02.047

[11] Huang, K., Hou, P.Y. and Goodenough, J.B. (2000) Characterization of Iron-Based Alloy Interconnects for Reduced Temperature Solid Oxide Fuel Cells. Solid State Ionics, 129, 237-250. https://doi.org/10.1016/S0167-2738(99)00329-X

[12] Sigghal, S.C. and Dokiya, M. (1999) Solid Oxide Fuel Cells (SOFC VI). Proceeding Volume 99-19. The Electrochemical Society, Inc., Pennington.

[13] Berthod, P. (2005) Kinetics of High Temperature Oxidation and Chromia Volatili- 
zation for a Binary Ni-Cr Alloy. Oxidation of Metals, 64, 235-252.

https://doi.org/10.1007/s11085-005-6562-8

[14] Asteman, H., Svensson, J.-E., Johansson, L.G. and Norell, M. (1999) Indication of Chromium Oxide Hydroxide Evaporation During Oxidation of $304 \mathrm{~L}$ at $873 \mathrm{~K}$ in the Presence of 10\% Water Vapor. Oxidation of Metals, 52, 95-111. https://doi.org/10.1023/A:1018875024306

[15] Ebbinghuaus, B.B. (1993) Combust. Flame, 93, 119-137. https://doi.org/10.1016/0010-2180(93)90087-J

[16] Brylewski, T., Nanko, M., Maruyama, T. and Przybylski, K. (2001) Application of Fe-16Cr Ferritic Alloy to Interconnector for a Solid Oxide Fuel Cell. Solid State Ionics, 143, 131-150. https://doi.org/10.1016/S0167-2738(01)00863-3

[17] Quadakkers, W.J., Piron-Abellan, J., Shemet, V. and Singheiser, L. (2003) Metallic Interconnectors for Solid Oxide Fuel Cells-A Review. Materials at High Temperatures, 20, 115-127.

[18] Han, M., Peng, S., Wang, Z., Yang, Z. and Chen, X. (2007) Properties of Fe-Cr Based Alloys as Interconnects in a Solid Oxide Fuel Cell. Journal of Power Sources, 164, 278-283. https://doi.org/10.1016/j.jpowsour.2006.10.039

[19] Mattar, T., Ahmed, A. and Ghali, S. (2008) Innovated High Temperature Oxidation-Resistant Cr-Steel. 27 th Annual Conference, Corrosion Challenges in Industry, Al-Ismailia, 25-27 November 2008, 1-11.

[20] Ghali, S., Ahmed, A. and Mattar, T. (2017) High Temperature Oxidation of New Developed Cr-Steel Interconnects in Solid Oxide Fuel Cells (SOFCs). 19th International Conference on Electrochemical Methods in Corrosion, Paris, 23-24 February 2017, 2960-2966.

[21] Ahmed, A., El-Fawakhry, M.K., Eissa, M. and Mattar, T. (2016) Thermal Compatibility of Chromium Steel as Metallic Interconnects for Solid Oxide Fuel Cells. Journal of Basic and Applied Research International, 14, 90-100.

[22] Holcomb, G.R. and Alman, D.E. (2006) Fabrication, Structure and Properties of $\mathrm{MoSi}_{2}$-Base Composites. Scripta Materialia, 54, 1821-1825. https://doi.org/10.1016/j.scriptamat.2006.01.026

[23] Yang, Z., Walker, M.S., Singh, P., Stevenson, J.W. and Norby, T. (2004) Oxidation Behavior of Ferritic Stainless Steels under SOFC Interconnect Exposure Conditions. Journal of the Electrochemical Society, 151, B669-B678. https://doi.org/10.1149/1.1810393

[24] Hammer, J.E., Laney, S.J., Jackson, R.W., Coyne, K., Pettit, F.S. and Meier, G.H. (2007) The Oxidation of Ferritic Stainless Steels in Simulated Solid-Oxide Fuel-Cell Atmospheres. Oxidation of Metals, 67, 1-38. https://doi.org/10.1007/s11085-006-9041-y

[25] Nehrenberg, A.E. (1946) Phosphorus Segregation in Austenite in Ni-Cr Steels. Transactions of AIME, 167, 494.

[26] Andrews, K.W. (1965) Heat Treatment for Improvement in Low Temperature Mechanical Properties of 0.40 pct C-Cr Steels. The Journal of the Iron and Steel Institute, 203, 721 .

[27] Wang, X. (1987) Metal Material Science. Machine Press, Beijing. (In Chinese)

[28] Xie, H., Wu, X. and Min, Y. (2008) Influence of Chemical Composition on Phase Transformation Temperature and Thermal Expansion Coefficient of Hot Work Die Steel. Journal of Iron and Steel Research, International, 15, 56-61. https://doi.org/10.1016/S1006-706X(08)60267-8 